\title{
Differential Expression of IGF-I Transcripts in Bladder Cancer
}

\author{
NIKOS MOURMOURAS ${ }^{1 *}$, ANASTASSIOS PHILIPPOU ${ }^{1 *}$, PANAGIOTIS CHRISTOPOULOS $^{1}$, \\ KATERINA KOSTOGLOU ${ }^{2}$, CHRISTOFORA GRIVAKI ${ }^{1}$, CHARALAMPOS KONSTANTINIDIS $^{3}$, \\ EFRAIM SERAFETINIDES ${ }^{3}$, DIMITRIOS DELAKAS ${ }^{3}$ and MICHAEL KOUTSILIERIS ${ }^{1}$ \\ ${ }^{1}$ Department of Physiology, Medical School, National and Kapodistrian University of Athens, Athens, Greece; \\ ${ }^{2}$ Department of Surgery, "Asklepieion" General Hospital, Athens, Greece; \\ ${ }^{3}$ Urology Clinic, “Asklepieion" General Hospital, Athens, Greece
}

\begin{abstract}
Background/Aim: A growing body of evidence shows that the differential expression of $E$ domain-related insulin-like growth factor-I (IGF-I) transcripts (IFG-IEa, $I G F-I E b$ and IGF-IEc) in normal and cancerous tissues, implicating specific biological roles for the putative $E a, E b$, and Ec peptides, beyond IGF-I. Herein, we investigated the expression profile of IGF-IEa, IGF-IEb and IGF-IEc transcripts in bladder cancer and compared them with samples from the normal adjacent bladder tissue. Materials and Methods: Biopsies from 46 patients (39 men and 7 women), aged $73.3 \pm 10.9$ years, were analyzed for the expression of IGF-I transcripts using semi-quantitative real time-PCR (qRT-PCR). Results: The presence of all three IGF-I transcripts was detected in both normal urothelium and bladder carcinomas. The relative expression of the IGF$I E a$ and IFG-IEb was marginally increased in bladder cancer tissues compared to normal tissue ( $p>0.05)$. In contrast, the expression of the IGF-IEc was significantly decreased in bladder cancer as compared to normal adjacent urothelium $(p<0.05)$. This specific suppression of IGF-IEc expression was evident and positively correlated with the histological and/or clinical characteristics of an advanced disease, referring to clinical stage, tumor grade and disease recurrence $(p<0.05)$; however, in situ carcinomas exhibited an increased expression of all IGF-I transcripts. Conclusion: Our data confirm the differential expression of IGF-I
\end{abstract}

\footnotetext{
*These Authors contributed equally to this study.

Correspondence to: Dr. Michael Koutsilieris, MD, Ph.D, Department of Physiology, Medical School, National and Kapodistrian University of Athens, 75 Micras Asias, Goudi, Athens, 115 27, Greece. Tel: +30 2107462506, Fax: +30 2107462571, e-mail: mkoutsil@med.uoa.gr
}

Key Words: Insulin-like growth factor I, IGF-IEa, IGF-IEb, IGFIEc, bladder cancer. transcripts in bladder cancer, revealing a distinct suppression of IGF-IEc. These findings suggest that IGF-IEc expression and putative Ec product may possess discrete biological role in disease progression beyond IGF-I.

Insulin-like growth factor-I (IGF-I) regulates various aspects of cellular function such as cell proliferation, differentiation, survival and migration, including cancer biology (1-6), thus IGF-I is implicated in the pathophysiology and disease progression of several human cancers (7-10). Using alternative splicing of exons 5 and 6 (E domain), the Igfl gene encodes three IGF-I transcripts, namely IGF-IEa, IGFIEb, and IGF-IEc (9). Several studies have investigated the differential expression of these IGF-I transcripts in various pathologies vis-à-vis the potential role of their putative products, namely the Ea, Eb and Ec peptides, beyond IGF-I (11-21). The biological significance of the IGF-I splice variants and their products is not fully understood, so far, despite the fact that an increasing body of evidence is pointing out for a complex and distinct IGF-I isoform-related expression pattern in the pathophysiology of various cancer models, both in vitro and in vivo $(9,14,22-24)$.

Although the role of IGF-I bioregulation system has been extensively investigated in several cancers, including prostate, breast and colon cancer $(2,14,24-28)$, the available data in bladder cancer is rather limited, while much less is known about the expression pattern of the IGF-I transcripts. High serum IGF-I levels have been associated with the risk of developing bladder cancer, however, no relationship was established between circulating IGF-I levels and disease stage (29). In addition, no significant correlation was documented either between preoperative plasma IGF-I levels and tumor characteristics in bladder cancer and disease outcome (30), or between serum IGF-I levels and tumor grade in patients with superficial bladder cancer (31). Nevertheless, there is a report suggesting that IGF-I may participate in the development and disease progression in bladder cancer, since the local expression of IGF-I was found 
to be increased in biopsies of bladder cancer as compared to normal urothelial tissues (32). It was further reported that a close relationship exists between IGF-I expression levels and disease recurrence, as well as, between IGF-I receptor (IGFIR) expression levels and tumor grade, tumor differentiation, and disease recurrence (32).

These data suggested that IGF-I may play an important role in bladder cancer, although no report exists on the expression pattern of E domain-related IGF-I transcripts in bladder cancer. Therefore, we characterized the expression profile of the IGF-I mRNA splice variants in bladder cancer biopsies in comparison with normal adjacent urothelium and in correlation to disease stage, tumor grade, disease recurrence and patient characteristics. Our data suggest that the IGF-IEc transcript is differentially regulated $v i s$ - $a$-vis the IGF-IEa and IGF-Eb in bladder cancer, being significantly suppressed. Such significant decrease of the IGF-IEc expression was correlated with advanced disease (i.e., high stage, grade, and recurrence). Interestingly, all the E domainrelated IGF-I transcripts, including IGF-IEc, were upregulated in biopsies from in situ carcinomas of urothelium as compared with normal adjacent urothelium.

\section{Materials and Methods}

Patients. Forty-six consecutive patients, 39 men and 7 women, (aged $73.3 \pm 10.9$ years) were included in the study. These patients were diagnosed with bladder cancer after clinical investigation of a history of macroscopic haematuria. They had undergone a full clinical, laboratory and imaging examination, while all patients had undergone cystoscopic examination, confirming exophytic lesions of their bladder and biopsies have histologically proven the diagnosis. The recommendation for surgery was according to the guidelines of the European Urology Association (EUA). No modification of the chronic medication of the patients was made except for the discontinuation of anticoagulant drugs before operation, while there was no restriction on their diet, physical activity, or caffeine and alcohol consumption. Because of the positive oncologic history of the patients, there were not exclusion criteria for the operation or participation in the study. A written informed consent was obtained by all patients before their inclusion to this study. The research protocol has been approved by the National and Kapodistrian University Ethics Committee and all the experimental procedures conformed to the Declaration of Helsinki.

Bladder biopsies and tissue processing. Bladder tissue biopsies were obtained from both the pathologic bladder lesion and the adjacent normal urothelial tissue, under spinal anaesthesia at surgery. The bladder tissue sample ( $\sim 50 \mathrm{mg})$ obtained from each biopsy was snap-frozen in liquid nitrogen and then stored at $-80^{\circ} \mathrm{C}$ until analyzed for RNA and protein content.

RNA extraction and semi-quantitative reverse transcriptionpolymerase chain reaction ( $q R T-P C R$ ) analysis. In order to identify differences in gene expression at the mRNA level between normal and pathological condition, expression profile of the IGF-I splice variants was considered on total RNA isolated from bladder biopsies
Table I. The sequence of the primer sets used in IGF-I mRNA variant RT-PCR analyses.

\begin{tabular}{lcc}
\hline Target mRNA & PCR primer sequence & $\begin{array}{c}\text { Product } \\
\text { size } \\
(\mathrm{bp})\end{array}$ \\
\hline IGF-IEa & 5'-GTGGAGACAGGGGCTTTTATTTC-3' & 251 \\
& 5'-CTTGTTTCCTGCACTCCCTCTACT-3' & \\
IGF-IEb & 5'-ATGTCCTCCTCGCATCTCT-3' & 411 \\
& 5'-CCTCCTTCTGTTCCCCTC-3' & \\
IGF-IEc & 5'-CGAAGTCTCAGAGAAGGAAAGG-3' & 150 \\
& 5'-ACAGGTAACTCGTGCAGAGC-3' & \\
\hline
\end{tabular}

of normal and cancerous tissue of the same patient, as previously described $(11,14)$.

Specifically, each tissue sample was homogenized and total RNA was isolated using Trizol Reagent (Invitrogen, Carlsbad, CA, USA), according to the manufacturer's recommendations. The extracted total RNA was dissolved in RNAases free water (Invitrogen) and the concentration and purity were determined spectrophotometrically (Nanodrop, ThermoFiser Scientific, Waltham, MA, USA) by absorption at 260 and $280 \mathrm{~nm}$. The quality and integrity of the RNA were further assessed by visual inspection of the electrophoretic pattern of $18 \mathrm{~S}$ and $28 \mathrm{~S}$ ribosomal RNA in ethidium bromide-stained $1 \%$ agarose gels under ultraviolet (UV) light and electrophoresis of the RNA confirmed that it was intact.

Total RNA $(1 \mu \mathrm{g})$ from each sample was used for the production of single-stranded cDNA by reverse transcription (SuperScript ${ }^{\mathrm{TM}}$ IV First-Strand Synthesis System, Invitrogen) and the resultant cDNA samples were utilized in real-time PCR. Real-time PCR analyses were performed using the Bio-Rad 96-well iCyclerThermal Cycler (iQ5 Real-Time PCR Detection System, Bio-Rad, Hercules, CA, USA) and iTaq ${ }^{\mathrm{TM}}$ Universal SYBR ${ }^{\circledR}$ Green Supermix (Bio-Rad). The primer set sequences used for the specific detection of IGF-I transcripts are shown in Table I. To prevent detection of genomic DNA, the primer sets were designed to lie within different exons while, particularly, each set of primers was specific to detect only one specific IGF-I splice variants.

Each PCR reaction contained $50 \mathrm{ng}$ of cDNA, $12.5 \mu \mathrm{S}$ SYBR green master mix, $0.4 \mu \mathrm{M}$ of each primer, and nuclease free water to a total volume of $25 \mu \mathrm{l}$. The real-time PCR parameters were the following: initial denaturation at $95^{\circ} \mathrm{C}$ for 4 min followed by 40 cycles of $15 \mathrm{sec}$ at $95^{\circ} \mathrm{C}$, and $30 \mathrm{sec}$ at $61^{\circ} \mathrm{C}$ for annealing, and 30 sec at $72^{\circ} \mathrm{C}$ for extension. To normalize the amount of total RNA present in each reaction, the geometric mean of two housekeeping genes, $\beta$-actin and cyclophilin, was used as internal standards. Transcript levels of the mRNA isoforms of interest were assessed by automatically calculating the threshold cycle $\left(C_{t}\right)$, as the number of cycles at which the measured fluorescence exceeds the threshold for detection, which is set slightly above background. Each sample was analyzed in duplicate, and the resulting data were averaged.

A melting curve $\left(\mathrm{T}_{\mathrm{m}}\right)$ was also generated by the Bio-Rad iQ5 Real-Time PCR Detection System software following the final cycle for each experimental sample, by continuous monitoring the SYBR green fluorescence throughout the temperature ramp from $65^{\circ} \mathrm{C}$ to $95^{\circ} \mathrm{C}$, in order to confirm the specificity of the primers. Moreover, 
Table II. Clinical and epidemiological characteristics of the patients.

\begin{tabular}{|c|c|c|c|c|c|c|}
\hline $\mathrm{n}$ & Gender & Recurrence & Cis & Deaths & Smokers & Upper urinary tract urothelial cell carcinoma \\
\hline 39 & Male & 6 & 4 & 6 & 21 & 4 \\
\hline 7 & Female & - & - & - & - & - \\
\hline
\end{tabular}

Cis: Carcinoma in situ.

all target IGF-I mRNA sequences were identified by sequencing analysis to ensure specificity of the primers and to further verify each target, while electrophoretic analysis of the real-time PCR products further verified the specificity of each target IGF-I mRNA. Controls for specificity included cDNA-free (i.e., RNA not reverse transcribed), and template-free (water) reactions.

Protein extraction and Western blot analysis. Total proteins were extracted from the same biopsy sample used for total RNA isolation using the Trizol Reagent protocol. The extracts were analyzed for total protein concentration using the Bradford procedure (Bio-Rad Protein Assay). Samples were stored in aliquots at $-80^{\circ} \mathrm{C}$ until analyzed by western blot, as previously described $(11,14)$. The following IGF-I isoform-specific primary antibodies were used for the immunodetection of the IGF-I isoforms at the protein level: antiIGF-IEa antibody (provided by Dr. Elisabeth R. Barton Lab), antiIGF-IEb antibody (provided by Dr. Julia Durzynska) and anti-IGFIEc antibody [raised in our laboratory (33)].

Statistical analysis. Wilcoxon signed-rank test was employed to evaluate potential differences in the expression level of each IGF-I splice variant between the normal and pathological samples (SPPS v. 21 statistical package; SPSS Inc., Chicago, IL, USA). All data are presented as mean \pm standard error of the mean (SEM). Statistically significant changes were considered at $p<0.05$.

\section{Results}

The demographics and disease characteristics of patients with bladder cancer participating in the study are presented in Table II. In addition, the tumor characteristics of the analyzed biopsies are given in Table III.

All the E domain-related IGF-I splice variants were documented at the mRNA level in both normal adjacent urothelium and bladder cancer biopsies. The expression of IGF-IEa and IGF-Eb were marginally $(p>0.05)$ increased compared to normal urothelium, while the expression of IGF-IEc was significantly $(p<0.05)$ decreased in bladder cancer biopsies (Figure 1A). These data suggest that IGF-I transcripts are differentially expressed in bladder cancer. Western blot analysis did not detect the IGF-IEa and IGF$\mathrm{IEb}$ isoform in either bladder cancer biopsies or normal urothelial tissues, probably due to their low protein expression levels in these tissues. The IGF-IEc was detected in normal urothelial tissues (Figure1B), while it was undetectable in bladder cancer biopsies, possibly due to the
Table III. Pathologoanatomic features of the patient bladder lesions.

\begin{tabular}{lcccccc}
\hline Stage & Ta & T1 & T2 & T3 & T4 & Total \\
\hline Low grade & 3 & 4 & - & - & - & 7 \\
High grade & 1 & 15 & 17 & 2 & 1 & 36 \\
Total & 4 & 19 & 17 & 2 & 1 & $43^{*}$ \\
\hline
\end{tabular}

*In one sample pathologoanatomical examination was not performed and in two samples no grade was reported.

down-regulation of this transcript in bladder cancer, as documented by qRT-PCR analysis.

Furthermore, by classifying bladder cancer samples in different subgroups based on the clinical stage, degree of tumor differentiation and clinical recurrence, or based on a combinational analysis of those characteristics, our study revealed that in $\mathrm{T} 1$ stage as well as in all high-grade tumors (Table III) the expression of IGF-IEc was found to be significantly decreased $(p<0.05)$. This was coming along with a steady differential, albeit non-significant $(p>0.05)$ increase in the expression of the transcripts IGF-IEa and IGF-IEb compared to the adjacent normal urothelium (Figure 2A, 2B). A similar expression pattern was detected in the subgroup of patients who were exhibited both the above pathological characteristics (i.e., stage T1 plus high-grade tumors) (Figure 2C).

Interestingly, the analysis of in situ carcinomas (Cis) revealed increasing expression levels of all three IGF-I transcripts vis-à-vis normal urothelium (data not shown), although $\mathrm{Cis}$ are superficial bladder cancers, as the $\mathrm{T} 1$ cancers.

When the expression of the IGF-I transcripts in papillary urothelial carcinoma was analyzed, either as an independent factor (Figure 3A), or in combination with the stage and degree of differentiation (stage T1, High-grade, or stage T1High grade tumors; Table III), or with the coexistence of solid urothelial cancer, IGF-IEc transcript exhibited significantly decreased expression levels $(p<0.05)$ while, again, the other splice variants (IGF-IEa and IGF-IEb) showed marginally $(p>0.05)$ elevated expression as compared with their relative expression in normal tissues (Figure 3A).

Moreover, in the group of the recurrent disease, a significant down-regulation of the IGF-IEc expression 
A

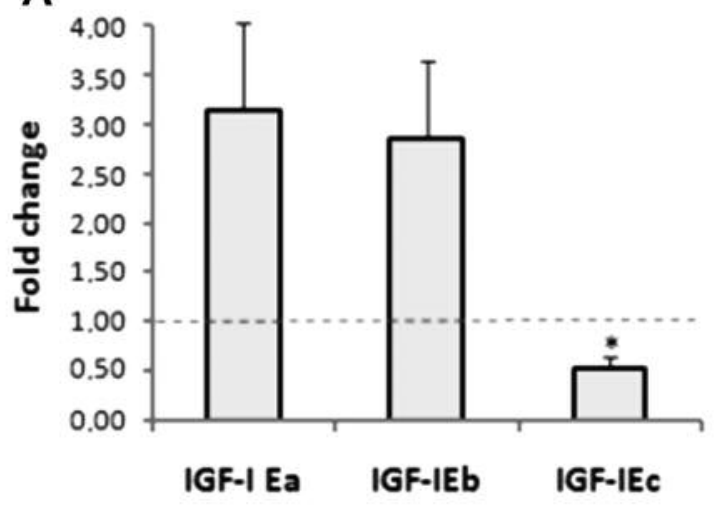

B

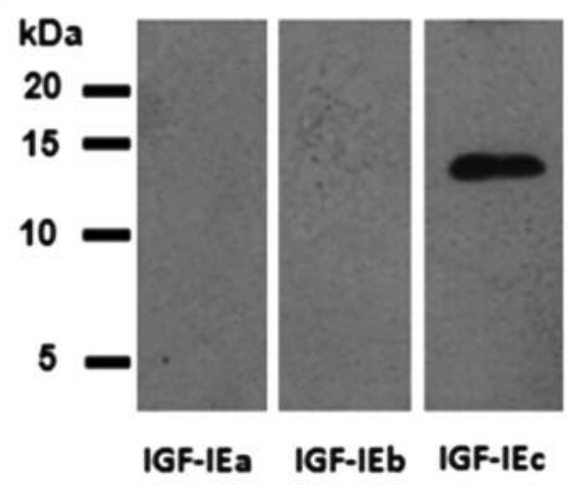

Figure 1. A: Expression of the different IGF-I isoforms at the transcriptional level (mRNA), in cancerous bladder tissue compared to normal adjacent urothelial tissue of the same patient $(n=43)$. Values (means $\pm S E$ ) were normalized to the geometric mean of two housekeeping genes $(\beta$-actin and cyclophilin) and expressed as fold changes compared to the values of the corresponding normal tissue for each patient. ${ }^{*} p<0.05$. B: Evidence for the expression of IGF-IEc transcript at the protein level in normal urothelial tissue detected by the anti-IGF-IEc specific antibody. IGF-IEa and IGF-IEb protein isoforms were not detected by the anti-IGF-IEa and anti-IGF-IEb antibodies.

A

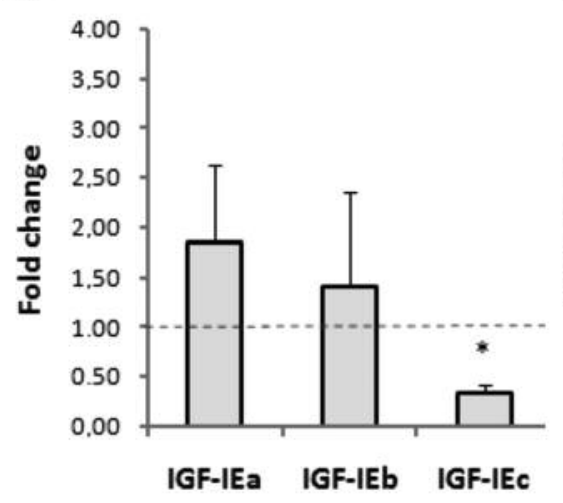

B

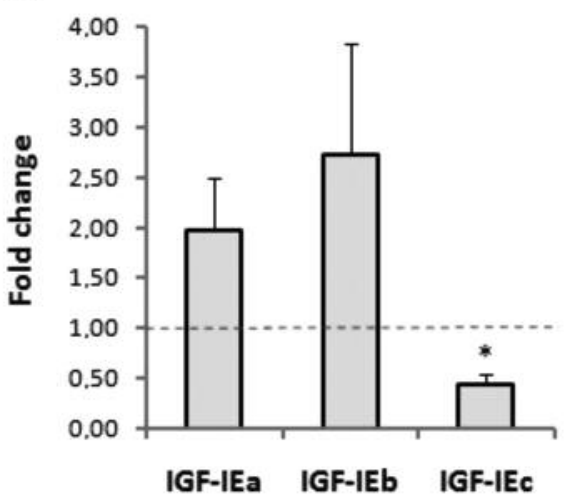

C

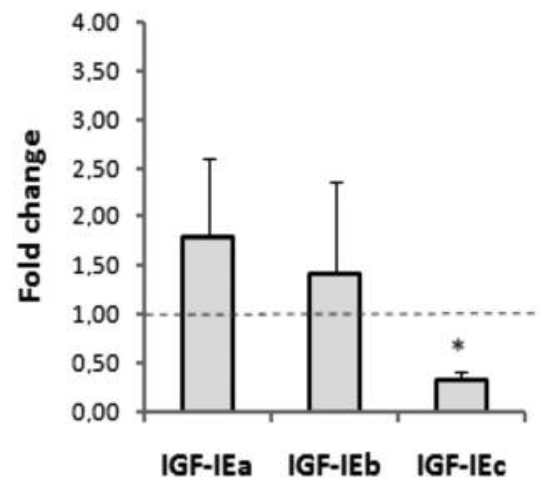

Figure 2. Expression of different IGF-I isoforms at the transcriptional level (mRNA) in (A) tumors stage T1 ( $n=19)$, (B) high-grade tumors ( $n=36)$ and $(C)$ in $T 1$ - high-grade tumors $(n=15)$ compared to normal adjacent urothelial tissue of the same patient. Values (means $\pm S E)$ were normalized to the geometric mean of two housekeeping genes ( $\beta$-actin and cyclophilin) and expressed as fold changes compared to the values of the corresponding normal tissue for each patient. ${ }^{*} p<0.05$.

$(p<0.05)$ was detected (Figure 3B). However, similar analysis in other classifications based on either tumor (Table III) or clinical characteristics (Table II) revealed no statistically significant differences in the expression profile of all the IGF-I transcripts $(p>0.05)$.

\section{Discussion}

This study investigated for the first time the expression profile of the different IGF-I splice variants in human bladder cancer with reference to the relative expression of the normal adjacent urothelium, in order to shed light on the possible role of these IGF-I isoforms in the pathophysiology of bladder cancer. Our findings documented that the expression of the IGF-IEc is significantly decreased in bladder cancer and that this regulation is to the opposite direction of the expression detected for the IGF-IEa and IGF$\mathrm{IEb}$ transcripts in bladder cancer. This provide for the first time evidence for a differential regulation of IGF-I transcripts in bladder cancer. Interestingly, this differential regulation was not found in the limited number of samples with in situ carcinomas. The down-regulation of the IGF-IEc 
A

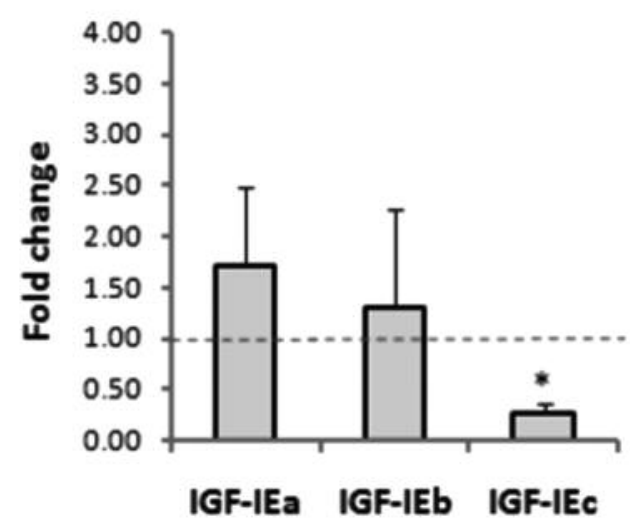

B

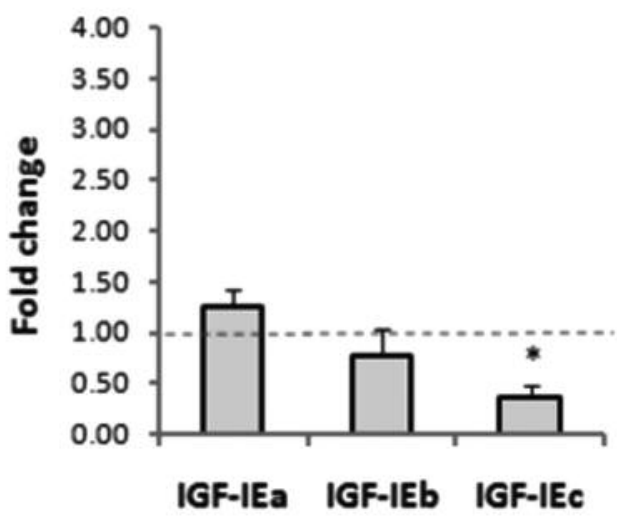

Figure 3. A: Expression of different IGF-I isoforms at the transcriptional level (mRNA), in papillary urothelial carcinoma compared to normal adjacent urothelial tissue of the same patient $(n=21)$. B: The expression of different IGF-I isoforms at the transcriptional level (mRNA), in recurrent tumors compared to normal adjacent urothelial tissue of the same patient $(n=6)$. Values (means $\pm S E)$ were normalized to the geometric mean of two housekeeping genes ( $\beta$-actin and cyclophilin) and expressed as fold changes compared to the values of the corresponding normal tissue for each patient. $* p<0.05$.

expression in urothelial cancer compared to normal urothelium, and the modest increases in the expression of the IGF-IEa and IGF-IEb variants in bladder cancer, were independent of the cancer stage or tumor grade.

IGF-I possesses a strong mitogenic and/or anti-apoptotic activity in a wide variety of cancers such as sarcoma, leukemia, prostate, breast, lung, colon, stomach, esophagus, liver, pancreas, kidney, thyroid, brain, ovary and uterus (cervix and endometrium) cancer (27, 34-36). Nevertheless, few studies have addressed the role of IGF-I and/or its receptor (IGF-IR) in bladder cancer. These studies have implicated IGF-I in the development and progression of bladder cancer, reporting that both the IGF-I and IGF-IR expression exhibited a tendency to be increased in bladder cancer $(32,37)$.

The investigation of the expression pattern of the IGF-I splice variants in various pathologies, including cancer (11$14,38)$, is of particular interest as it may indicate a distinct biological role for the putative $\mathrm{Ea}, \mathrm{Eb}$ and Ec peptides, which are produced by such transcripts and possibly have a discrete role beyond (mature) IGF-I, which is the common product of all splice variants. However, the role of the putative $\mathrm{Ea}, \mathrm{Eb}$ and Ec peptides remain as yet unclear (39).

Our group focused on the investigation of IGF-I transcripts in cancer biology and for the first time we have reported the differential IGF-IEc expression in human prostate cancer along with strong evidence for IGF-I overexpression in human prostate cancer tissue (14). Moreover, IGF-IEc expression was positively correlated with the prostate cancer stage and Gleason's score (40). In addition, we documented an increased expression of IGF-IEc isoform in secondary compared to primary foci of neuroendocrine neoplasms (18). Other investigators have reported the overexpression of IGF-IEa and IGF-IEb in multiple myeloma patients (41) and of IGF-IEb in uterine cancer (23).

Lower expression of total IGF-I mRNA as well as of each particular IGF-I transcript has been observed in colorectal cancer compared to normal colon tissue (24). More specifically and similarly to our findings, Kasprzak et al. (24) found no significant differences between the expression of IGF-IEa and IGF-IEb splice variant in colon cancer, while both these mRNA isoforms exhibited higher expression compared to IGF-IEc. Overall, there is a growing body of evidence indicating a differential regulation of the IGF-I isoforms in the pathophysiology of cancer, which may be tumor type-specific.

Another interesting finding of our study was the increased, though no significant, expression of all three IGF-I isoforms in the in situ carcinoma compared to the T1 tumors. Since both carcinoma in situ and T1 tumors belong to the superficial disease, similar expression levels might be expected in both cases and this circumstantial evidence may suggest a specific regulation of IGF-I isoforms in surface tumors with possible predictive value.

In conclusion, the differential mRNA expression pattern of the IGF-IEc isoform, compared to the other IGF-I transcripts suggests, an isoform-specific regulation of IGF-I expression in the pathophysiology of urothelial carcinoma and supports the notion that the $\mathrm{Ea}, \mathrm{Eb}$, and Ec peptides may possess discrete biological roles, beyond IGF-I. Recently, the synthetic Ec peptide (24 aa) was documented to possess bioactivity which was exerted via an IGF-I receptor- 
independent manner (20), while its over-expression in PC-3 cells resulted in Ec-PC-3 cells, which were found to possess increased oncogenic potential in SCID mice (26). Further studies shall investigate the mechanism(s) through which IGF-I transcripts may influence bladder cancer biology.

\section{Acknowledgements}

The Authors are indebted to the volunteer patients for their invaluable contribution to this study.

\section{References}

1 Reyes-Moreno C, Sourla A, Choki I, Doillon C and Koutsilieris M: Osteoblast-derived survival factors protect PC-3 human prostate cancer cells from adriamycin apoptosis. Urology 52 : 341-347, 1998.

2 Koutsilieris M, Mitsiades C and Sourla A: Insulin-like growth factor I and urokinase-type plasminogen activator bioregulation system as a survival mechanism of prostate cancer cells in osteoblastic metastases: development of anti-survival factor therapy for hormone-refractory prostate cancer. Mol Med 6: 25167, 2000.

3 LeRoith D and Roberts CT Jr.: The insulin-like growth factor system and cancer. Cancer Lett 195: 127-137, 2003.

4 Kooijman R: Regulation of apoptosis by insulin-like growth factor (IGF)-I. Cytokine Growth Factor Rev 17: 305-23, 2006.

5 Mitsiades CS, Mitsiades $\mathrm{N}$ and Koutsilieris M: The Akt pathway: molecular targets for anti-cancer drug development. Curr Cancer Drug Targets 4: 235-256, 2004.

6 Koutsilieris M and Tolis G: Long-term follow-up of patients with advanced prostatic carcinoma treated with either buserelin (HOE 766) or orchiectomy: classification of variables associated with disease outcome. Prostate 7: 31-39, 1985.

7 Werner $\mathrm{H}$ and LeRoith D: The role of the insulin-like growth factor system in human cancer. Adv Cancer Res 68: 183-223, 1996.

8 Werner $\mathrm{H}$ and Bruchim I: The insulin-like growth factor-I receptor as an oncogene. Arch Physiol Biochem 115: 58-71, 2009.

9 Philippou A, Armakolas A and Koutsilieris M: Evidence for the possible biological significance of the igf-1 gene alternative splicing in prostate cancer. Front Endocrinol (Lausanne) 4: 31, 2013.

10 Philippou A, Christopoulos PF and Koutsilieris M: Clinical studies in humans targeting the various components of the IGF system show lack of efficacy in the treatment of cancer. Mutat Res Rev Mutat Res 772: 105-122, 2016.

11 Philippou A, Papageorgiou E, Bogdanis G, Halapas A, Sourla A, Maridaki M, Pissimissis N and Koutsilieris M: Expression of IGF-1 isoforms after exercise-induced muscle damage in humans: characterization of the MGF E peptide actions in vitro. In Vivo 23: 567-575, 2009.

12 Stavropoulou A, Halapas A, Sourla A, Philippou A, Papageorgiou E, Papalois A and Koutsilieris M: IGF-1 expression in infarcted myocardium and MGF E peptide actions in rat cardiomyocytes in vitro. Mol Med 15: 127-135, 2009.

13 Milingos DS, Philippou A, Armakolas A, Papageorgiou E, Sourla A, Protopapas A, Liapi A, Antsaklis A, Mastrominas M and Koutsilieris M: Insulinlike growth factor-1Ec (MGF) expression in eutopic and ectopic endometrium: characterization of the MGF E-peptide actions in vitro. Mol Med 17: 21-28, 2011.

14 Armakolas A, Philippou A, Panteleakou Z, Nezos A, Sourla A, Petraki $C$ and Koutsilieris M: Preferential expression of IGF-1Ec (MGF) transcript in cancerous tissues of human prostate: evidence for a novel and autonomous growth factor activity of MGF E peptide in human prostate cancer cells. Prostate 70 : 1233-1242, 2010.

15 Philippou A, Armakolas A, Panteleakou Z, Pissimissis N, Nezos A, Theos A, Kaparelou M, Armakolas N, Pneumaticos SG and Koutsilieris M: IGF1Ec expression in MG-63 human osteoblastlike osteosarcoma cells. Anticancer Res 31: 4259-4265, 2011.

16 Christopoulos PF, Philippou A and Koutsilieris M: Pattern of IGF-1 variants' expression in human cancer cell lines using a novel q-RT-PCR approach. Anticancer Res 35: 107-115, 2015.

17 Gkioka E, Msaouel P, Philippou A, Vlaghogiannis NI, Vogkou CT, Margiolis A and Koutsilieris M: Review: The role of insulinlike growth factor-1 signaling pathways in uterine leiomyoma. In Vivo 29: 637-649, 2015.

18 Alexandraki KI, Philippou A, Boutzios G, Theohari I, Koutsilieris M, Delladetsima IK and Kaltsas GA: IGF-IEc expression is increased in secondary compared to primary foci in neuroendocrine neoplasms. Oncotarget 8: 79003-79011, 2017.

19 Msaouel P, Pissimissis N, Halapas A and Koutsilieris M: Mechanisms of bone metastasis in prostate cancer: clinical implications. Best Pract Res Clin Endocrinol Metab 22: 341-355, 2008.

20 Papageorgiou E, Philippou A, Armakolas A, Christopoulos PF, Dimakakos A and Koutsilieris M: The human Ec peptide: the active core of a progression growth factor with species-specific mode of action. Hormones (Athens) 15: 423-434, 2016.

21 Vassilakos G, Philippou A and Koutsilieris M: Identification of the IGF-1 processing product human Ec/rodent Eb peptide in various tissues: Evidence for its differential regulation after exercise-induced muscle damage in humans. Growth Horm IGF Res 32: 22-28, 2017.

22 Kuo YH and Chen TT: Novel activities of pro-IGF-I E peptides: regulation of morphological differentiation and anchorageindependent growth in human neuroblastoma cells. Exp Cell Res 280: 75-89, 2002.

23 Koczorowska MM, Kwasniewska A and Gozdzicka-Jozefiak A: IGF1 mRNA isoform expression in the cervix of HPV-positive women with pre-cancerous and cancer lesions. Exp Ther Med 2: 149-156, 2011.

24 Kasprzak A, Szaflarski W, Szmeja J, Andrzejewska M, Przybyszewska W, Kaczmarek E, Koczorowska M, Kościński T, Zabel $\mathrm{M}$ and Drews M: Differential expression of IGF-1 mRNA isoforms in colorectal carcinoma and normal colon tissue. Int $\mathrm{J}$ Oncol 42: 305-316, 2013.

25 Koutsilieris M, Reyes-Moreno C, Sourla A, Dimitriadou V and Choki I: Growth factors mediate glucocorticoid receptor function and dexamethasone-induced regression of osteoblastic lesions in hormone refractory prostate cancer. Anticancer Res 17: 14611465, 1997.

26 Armakolas A, Kaparelou M, Dimakakos A, Papageorgiou E, Armakolas N, Antonopoulos A, Petraki C, Lekarakou M, Lelovas P, Stathaki M, Psarros C, Donta I, Galanos PS, Msaouel $\mathrm{P}$, Gorgoulis VG and Koutsilieris M: Oncogenic role of the Ec peptide of the IGF-1Ec isoform in prostate cancer. Mol Med 21: 167-179, 2015. 
27 Singh P, Dai B, Yallampalli U, Lu $\mathrm{X}$ and Schroy PC: Proliferation and differentiation of a human colon cancer cell line $(\mathrm{CaCo} 2)$ is associated with significant changes in the expression and secretion of insulin-like growth factor (IGF) IGFII and IGF binding protein-4: role of IGF-II. Endocrinology 137: 1764-1774, 1996

28 Christopoulos PF, Msaouel P and Koutsilieris M: The role of the insulin-like growth factor-1 system in breast cancer. Mol Cancer 14: 43, 2015.

29 Zhao H, Grossman HB, Spitz MR, Lerner SP, Zhang K and Wu $\mathrm{X}$ : Plasma levels of insulin-like growth factor-1 and binding protein-3, and their association with bladder cancer risk. J Urol 169: 714-717, 2003.

30 Shariat SF, Kim J, Nguyen C, Wheeler TM, Lerner SP and Slawin KM: Correlation of preoperative levels of IGF-I and IGFBP-3 with pathologic parameters and clinical outcome in patients with bladder cancer. Urology 61: 359-364, 2003.

31 Serel TA, Turan T, Soyupek S, Aybek Z and Perk H: Urine and serum free IGF-1 levels in patients with bladder cancer: a brief report. Urol Res 31: 297-299, 2003.

32 Xie QX, Lin XC, Zhang MF, Han CX and Guo YH: Expression of IGF-I and IGF-IR in bladder cancer. Ai Zheng 23: 707-709, 2004.

33 Philippou A, Stavropoulou A, Sourla A, Pissimissis N, Halapas A, Maridaki M and Koutsilieris M: Characterization of a rabbit antihuman mechano growth factor (MGF) polyclonal antibody against the last 24 amino acids of the E domain. In Vivo 22: 2735, 2008.

34 LeRoith D, Baserga R, Helman L and Roberts CT Jr.: Insulinlike growth factors and cancer. Ann Intern Med 122: 54-59, 1995.

35 Yaginuma Y, Nishiwaki K, Kitamura S, Hayashi H, Sengoku K and Ishikawa M: Relaxation of insulin-like growth factor-II gene imprinting in human gynecologic tumors. Oncology 54: 502507, 1997.
36 Frostad S and Bruserud O: In vitro effects of insulin-like growth factor-1 (IGF-1) on proliferation and constitutive cytokine secretion by acute myelogenous leukemia blasts. Eur J Haematol 62: 191-198, 1999.

37 Sun HZ, Wu SF and Tu ZH: Blockage of IGF-1R signaling sensitizes urinary bladder cancer cells to mitomycin-mediated cytotoxicity. Cell Res 11: 107-115, 2001.

38 Thomas CG, Psarros C, Gekas A, Vandoros GP, Philippou A and Koutsilieris M: Alternative Splicing of IGF1 Gene as a Potential Factor in the Pathogenesis of Peyronie's Disease. In Vivo 30: 251-256, 2016.

39 Philippou A, Maridaki M, Pneumaticos S and Koutsilieris M: The complexity of the IGF1 gene splicing, posttranslational modification and bioactivity. Mol Med 20: 202-214, 2014.

40 Savvani A, Petraki C, Msaouel P, Diamanti E, Xoxakos I and Koutsilieris M: IGF-IEc expression is associated with advanced clinical and pathological stage of prostate cancer. Anticancer Res 33: 2441-2445, 2013.

41 Shushanov SS, Mar'ina LG, Kravtsova TA, Chernykh YB and Kakpakova ES: Coexpression of two mRNA isoforms of insulinlike growth factor-1 gene and mRNA of YB-1 gene in patients with multiple myeloma. Bull Exp Biol Med 154: 654-657, 2013.

Received April 13, 2018

Revised May 10, 2018

Accepted May 11, 2018 